\title{
The Artistic Object and Its Worlds
}

\section{Literature and Cinema}

\author{
Michael Wood \\ Princeton University, Princeton, NJ, USA \\ mwood@princeton.edu \\ Delia Ungureanu | ORCID: 0000-0002-0202-6373 \\ University of Bucharest, Bucharest, Romania and Harvard University, \\ Cambridge, MA, USA \\ deliaungureanu@fas.harvard.edu
}

This issue of the Journal of World Literature seeks to bring together two fields of study that have much in common, but that have been largely separate in practice. Literary scholars rarely discuss films apart from occasional direct adaptations, and while world cinema has sometimes looked at the theoretical framing developed in world literature studies, neither discipline has thought more generally beyond its respective medium. Yet writers, painters, musicians, and filmmakers hardly ever think in terms of disciplinary boundaries, and they do not develop their art with a tunnel vision. Modern writers have all grown up in an expansive mediascape, while many filmmakers have had extensive literary training. The essays in this issue aim to move beyond adaptation studies and intermedial studies to look more closely at how ideas circulate between media, creating for literary and film studies something of the complexity and openness to each other that the different media themselves have long enjoyed.

André Bazin, the seminal theorist of cinema with a degree in literature from the École Normale Supérieure, argued in a 1951 essay "The Grandeur of Limelight" that the best way to be an artist is not to serve a particular art (137). A contributor to Jean George Auriol's avant-garde and surrealist La Revue du cinéma (1928-1931, 1946-1949) which later turned into Cahiers du cinéma, Bazin defined cinema as a new form of realism that revealed what exists in reality 
beyond what our habits of perception allow us to see. Virginia Woolf had seen this as early as 1926. In her essay "Cinema," she wrote that the things we see on film "have become not more beautiful in the sense in which pictures are beautiful, but shall we call it (our vocabulary is miserably insufficient) more real, or real with a different reality from that which we perceive in daily life?". If the object of study of two disciplines - world literature and world cinema - is less neatly defined within the boundaries of a given art, perhaps the methods that seek to explain it should learn from its hybridity to understand it in the complexity in which their creators first imagined it.

\section{World Literature and World Cinema}

It's generally agreed that the rebirth of Goethe's Weltliteratur began around the turn of this century with Pascale Casanova's La République mondiale des Lettres (1999), Franco Moretti's "Conjectures on World Literature" (2000), and David Damrosch's What Is World Literature? (2003), whereas the discipline of world cinema begins with Stephanie Dennison and Song Hwee Lim's edited collection Remapping World Cinema (2006).

The infrequent dialogue between these two disciplines has mostly been from world cinema scholars with literary interests who have looked at world literature for theoretical guidance. Dudley Andrew's article "An Atlas of World Cinema" (2004) provided the discipline of world cinema with its theoretical backbone: the cartographic dimension that is behind most current work in world cinema. Inspired by Moretti's Atlas of the European Novel (1997) and Damrosch's What Is World Literature?, Andrew defines world cinema as an atlas where "displacement, not coverage, matters most" (10). In world literature studies, however, the cartographic dimension is only one among many, with a diversity of approaches that go from revisiting received ideas in comparative studies to postcolonial and translation studies, sociology, and world-system analysis among others.

Film studies has tended to define the geography of world cinema largely in terms of nonwestern productions. "What is world cinema? ... perhaps this is not the right question to ask in the first place," write the editors of Remapping World Cinema, Stephanie Dennison and Song Hwee Lim (1). For them, "'world cinema' is analogous to 'world music' and 'world literature' in that they are categories created in the Western world to refer to cultural products and practices that are mainly non-Western" (1). Whereas this is true of "world music," it is not true of "world literature," a term that on the contrary was traditionally used in comparative literature mostly as a synonym for the Western 
canon, or at best for "NATO literatures" (Werner Friederich). Simultaneously with the political debate sparked by postcolonialists to open up the Western canon that had included mainly masterpieces and classics of Western world literature, a perfect example being Harold Bloom's Western Canon (1994), the general editors of the two most influential American anthologies of world literature - David Damrosch for Longman and Martin Puchner for Norton - felt the need to rethink the notion, in theory and in practice. They included more and more works not traditionally part of the canon, and especially works from other places than Europe. Dennison and Song's neglect of this history is surprising, since their introduction cites Damrosch's book, which refers equally to Western and non-Western literature from a comparative perspective. The same misunderstanding of "world literature" as non-Western literature is perpetuated also by the Routledge Companion to World Cinema as recently as 2017 (2).

\section{The Comparative Dimension}

In the footsteps of Dudley Andrew's cartographic approach, world cinema has mainly dealt with non-Western cinema, and usually in national or at most regional terms. Paul Cooke's World Cinema's 'Dialogues' with Hollywood reinforces the very disjuncture he wants to mitigate. In their introduction to Theorizing World Cinema (2011), Lúcia Nagib, Chris Perriam, and Rajinder Dudrah present a very inclusive notion that presents world cinema as a polycentric phenomenon, shifting around the world, but like the very comprehensive Routledge Companion to World Cinema, their collection pins nationally or regionally defined cinemas on the map through problems mainly related to postcolonialism, the globalizing world, politics, race, identity, transnationalism. The comparative dimension that is at the heart of world literature theory is not common in world cinema. A notable exception is Rosalind Galt and Karl Schoonover's edited collection Global Art Cinema (2010): "art cinema retains at its core both a comparativist impulse and an internationalist scope" (3). However, this comparative dimension doesn't involve different media, but rather binaries like "mainstream / avant-garde, local / cosmopolitan, history / theory and industrial / formal debates" (9). Such binaries are similarly retained in the 2010 collection Cinema at the Periphery (Iordanova et al.), whose editors aim "to shift established paradigms of world cinema ... by making the periphery the center of our study" (6), "thus sparing the need of the investigation to constantly engage with the center, and effectively bracketing the center out" (4). 
For their part, many world literature scholars are trained in comparative literature, but their comparisons are rarely made across media. In What Is World Literature? Damrosch defines world literature as that which gains in translation, but he means translation into another language, not another medium. More recently, both Damrosch (Comparing the Literatures) and Rebecca Walkowitz (Born Translated) have worked on digital literature by the Korean digital art group Young-hae Chang Heavy Industries, but YнCHI's textual narratives rarely have any images, and are closer to animated prose poems than to cinema. World literature studies has as much to learn from cinema studies as world cinema has to learn from world literature.

\section{4}

\section{Rethinking Circulation}

Whereas world literature studies focus on the works' circulation in translation, world cinema understands the problem of circulation more pragmatically: usually, the distribution network of a film, or sometimes the circulation of filmic ideas and practices between different filmmakers. Dudley Andrew takes up circulation as the parameter for defining a more specific branch of world cinema he's interested in: global art cinema. "World literature comprises not just a huge bibliography of works, but more pertinently the complex interactions among these works" (Andrew "Foreword" vi). Similarly, he continues, "insofar as [films] remain within the culture, discovered perhaps by scholars interested in those cultures, they do not participate in the cultural economy of world film and certainly do not belong to anything one would label global art cinema" (vii). Seeking to expose "otherwise unseen geopolitical fault lines of world cinema," the editors of Global Art Cinema Rosalind Galt and Karl Schoonover mediate "between the aesthetic and the geopolitical or ... between cinema and the world" (3). They give a more political meaning to the idea of circulation than Andrew, tying it into a Marxist view that takes global art cinema in the vicinity of Pheng Cheah's understanding of politically committed world literature, and the leftist internationalism of the Warwick Research Collective (Combined and Uneven Development): "Internationalism understands the circulation of films across national borders as a political act ... While the Marxist history of internationalism might not always fit snugly with our analysis of global art cinema, the demand for a geopolitics of cinema remains an important spur" (Global Art Cinema 12).

But the history of the avant-garde that world cinema invokes is more than Marxist internationalism. It speaks of artists who practice different art forms with no disciplinary or medium boundaries in mind. André Bazin, whose ideas 
continue to form the discipline's most solid and wide-ranging theoretical corpus, had a literature degree, was a connoisseur of the history of art, and was trained in an international group of intellectuals at Auriol's Revue du cinéma, the same magazine that published Man Ray as a photographer and filmmaker, photos by the surrealist painter Jacqueline Lamba, and the surrealist poet Philippe Soupault's film essays.

In a major essay from $195^{2}$ "In Defense of Mixed Cinema,"1 Bazin put forth his own version of the concept of circulation as adaptation to a different medium of an idea previously found in another: "adaptations which the modern critic looks upon as a shameful way out are an established feature of the history of art" (56). This exchange of ideas is never unidirectional, say from literature to film. In 1921, the language of film sparked André Breton's interest in a new form of automatic poetry, which he describes in a letter to Simone Khan: "Yesterday I had a strange idea for writing poetry by copying a film's intertitles. This makes language incredibly picturesque ... the poem can benefit greatly from this [lack of visual action]" (146). Bazin describes the reverse process: "the making of films that dare to take their inspiration from a novel-style one might describe as ultra-cinematographic" ("In Defense" 64). Akira Kurosawa would agree: "In order to write scripts, you must first study the great novels and dramas of the world. ... You must read thoroughly ... If your goal is to become a film director, you must master screenwriting” (193). In the same vein as Bazin, Kurosawa observes: "Cinema resembles so many other arts. If cinema has very literary characteristics, it also has theatrical qualities, a philosophical side, attributes of painting and sculpture and musical elements. But cinema is, in the final analysis, cinema" (191).

Bazin's idea of translation prefigures Lawrence Venuti's understanding that "translation changes everything" in a positive sense. Translation, as Bazin understood it, was also translation between media, in this case, from literature to film: "the filmmakers honestly attempt an integral equivalent, they try at least not simply to use the book as an inspiration, not merely to adapt it, but to translate it onto the screen" ("In Defense" 66). In Comparing the Literatures, Damrosch touches on this very understanding: "intermedial work is as much a matter of translation as of interpretation" (236).

1 The original French title, "Pour un cinéma impur: défense de l' adaptation," could equally be translated "impure" as it sets up Bazin's critique of "pure" cinema. This is the proposal of Lúcia Nagib and Anne Jerslev, editors of Impure Cinema:Intermedial and Intercultural Approaches to Film (2014). While "impure" takes a clear polemic stance against the purists of cinema, Hugh Gray's translation of "impur" as "mixed" captures the primary focus of Bazin's argument for the value of mixing different artistic modes. 
The essays selected in this issue illustrate the diversity of methods and approaches through which we can scrutinize the complexity of a hybrid object of study. They invite us to rethink major issues at the heart of our world-scale disciplines: translation, multiple cultural centers, medium specificity, nostalgia, relocations, reimaginings, building the global through the national, points of view, impurity, library, possibility of the medium, cosmopolitanism, cultural specificity, intellectual instruments. Although diverse, they are all different takes on the problem of circulation. The methods the essays employ replicate the hybridity of the object of study. Among these, we find the comparative historical dimension of world literature interested in the relation between word, medium and locality, the translational approach, the sociological dimension of Pierre Bourdieu and Pascale Casanova's field theory, adaptation theory, the complex problem of circulation between media based on archives, from the point of view of postcolonial studies, or of game studies.

\subsection{The Possibility of the Medium}

From the beginning, the relation between script, prop, and world has been at the heart of cinema, structured around a concept of authenticity that has evolved in time according to technological developments and the budget available. For Akira Kurosawa, this relationship is vital in a film: "I am often accused of being too exacting with sets and properties, of having things made, just for the sake of authenticity, that will never appear on camera.... The first Japanese director to demand authentic sets and props was Mizoguchi Kenji, and the sets in his films are truly superb" (197). In a similar vein, David Damrosch's essay "Page, Stage, Location: The Work in the World" sketches a short history of the relation between text, prop, and location from the fiction of Marguerite Duras and Eileen Chang to films like Michael Curtiz's Casablanca, Jean-Jacques Annaud's L'Amant, and Ang Lee's Lust, Caution. This history reveals an increasing need for authenticity in global cinema, as locality anchored in the real referential world.

\subsection{Translation}

Sometimes the hybridity of the object mirrors the hybridity of the social, cultural and political space in which it's created. Tara Coleman looks comparatively at two Hong Kong artists: the filmmaker Wong Kar-wai, a "lyrical cinematic stylist," and the poet Leung Ping-kwan, to illustrate how translation functions in a space that is linguistically and culturally a world in itself. 


\subsection{Cosmopolitanism and Multiple Cultural Centers}

The sociological approach brought to world literature by Pascale Casanova's influential book continues to illuminate new venues of circulation, this time beyond the medium of production. Ignacio M. Sánchez Prado's contribution exemplifies the recent developments of the concept of circulation in world literature. Looking at the Mexican comedian Cantinflas's cinematic recreations of masterpieces of world literature, Sánchez-Prado proposes that cinema can promote a form of "popular cosmopolitanism, which democratizes and massifies world literature in Mexico." In the context of an increasingly important Black Lives Matter movement, circulation must consider issues of race and inequality. Claire Tomasella finds in the works of James Baldwin the roots of the language that can deconstruct racialization in Raoul Peck's documentary I Am Not Your Negro (2016). His film creates a meaningful dialogue with Baldwin's writing that reflects back on Baldwin's place and importance.

\subsection{Medium Specificity}

"The novel it is that has made the subtlest use of montage," Bazin notes ("In Defense" 64). The Hungarian filmmaker Béla Tarr learned this lesson from László Krasznahorkai's novels, as Cezar Gheorghe illustrates in his close reading of Sátántangó (1994) and Werckmeister Harmonies (2000).

\subsection{Nostalgia, Relocations, Reimaginings}

Similarly, Laura Marcus analyses the translation of André Aciman's novel Call Me By Your Name into Luca Guadagnino's 2017 film, with an eye on the construction of nostalgia in relation to time. As Bazin said, "it was montage that gave birth to film as an art, setting it apart from mere animated photography, in short, creating a language" ("The Evolution" 25).

\subsection{Impurity}

In his essay "In Defense of Mixed Cinema," Bazin wrote: "When the cinema actually began to follow in the footsteps of theatre, a link was restored, after a century or two of evolution, with dramatic forms that had been virtually abandoned" (58). The essay that most closely illustrates Bazin's notion of mixed or "impure cinema" is Annalisa Mirizio's. Focusing on Pier Paolo Pasolini's work as a writer, filmmaker, theatre director, poet, and essayist, Mirizio demonstrates how this free circulation of ideas was possible thanks to Pasolini's "librarylaboratory". "After Pasolini and Godard, the library would become the site of the filmmaker at work," she concludes. As Mirizio shows, in Pasolini's case impurity in cinema means also turning to forms of poetry and theoretical notions of realism. 


\subsection{Building the Global through the National}

Bazin suggested that we should "study the influence of modern literature on film-makers" ("In Defense" 62), but also the other way around. Luis A. Medina Cordova looks at Ecuadorian Gabriela Alemán's writings that are influenced by the Spanish filmmaker Jesús "Jess" Franco and more particularly by Orson Welles's radiophonic adaptation of H.G. Wells's The War of the Worlds. By turning Ecuador into the center of Wells's rewritten narrative, Alemán "decentres and recentres world literature" as she makes the periphery into a center.

\subsection{Cultural Specificity, Intellectual Instruments}

Attentive to the latest form that artistic ideas take, Bazin always had an eye out for what scholars dismissed as too trivial to engage with: "Did those same learned historians who know everything there is to be known about farce in the sixteenth century ever make it their business to find out what a resurgence of vitality it had between 1910 and 1915 at the Pathé and Gaumont studios and under the baton of Mack Sennett?" ("In Defense" 58-9). The same applies to video games, this new form situated between film and literature that raises ethical issues in our globalized world. We close this issue with Michael O'Krent's article on video games that revisit Greek mythology and take their cue from the narrative construction of different literary genres like the pastoral, "embracing ecofeminist calls to reconstruct rationality while challenging existing sexism in computing fields."

Discussing possible ways to define cinema, the Chilean filmmaker Raúl Ruiz described a film project he never got to do:

Several years ago I had an idea for a film: a competition between Georges Méliès and the Lumière Brothers to produce a movie of Around the World in 80 Days, for screening at the 1900 World Exhibition in Paris. Because the promoters can't decide which project to back, they go directly to Jules Verne and ask his opinion. Verne supports both projects, so Méliès and the Lumières each have eighty days to make a film. The Lumières decide to spend eighty days traveling around the world with their camera, whereas Méliès chooses to remain in Paris and use special effects to recreate the trip in his studio.

RUIZ 74

Ruiz's story that never became a film is a parable about the nature of the relationship between art and the world. It is also a parable about the origins of cinema in the other arts including literature, whose relation to the world is at 
the same time real and imaginary, physically mapped and artistically dreamed, a world travelled in the body and in the mind.

\section{Works Cited}

Andrew, Dudley. "An Atlas of World Cinema." Framework: The Journal of Cinema and Media. 45:2 (Fall 2004), 9-23.

Andrew, Dudley. "Foreword." In Global Art Cinema: New Theories and Histories. Eds. Rosalind Galt and Karl Schoonover. Oxford: Oxford UP, 2010, v-xi.

Bazin, André. "In Defense of Mixed Cinema." In What is Cinema? 2 vols. Ed. and trans. Hugh Gray. Berkeley: University of California Press, 2005, 1: 53-75.

Bazin, André. "The Evolution of the Language of Cinema." In What is Cinema?, 1: 23-40. Bazin, André. "The Grandeur of Limelight." What is Cinema?, 2: 128-39.

Bloom, Harold. The Western Canon: The Books and School of the Ages. San Diego: Harcourt Brace, 1994.

Breton, André. Lettres à Simone Khan 1920-1960. Ed. Jean-Michel Goutier. Paris: NRF Gallimard, 2016.

Casanova, Pascale. La République mondiale des Lettres. Paris: Éditions du Seuil, 1999.

Cheah, Pheng. What is a World? On Postcolonial Literature as World Literature. Durham: Duke UP, 2016.

Cooke, Paul. World Cinema's 'Dialogues' with Hollywood. London: Palgrave Macmillan, 2007.

Damrosch, David. Comparing the Literatures. Princeton: Princeton UP, 2020.

Damrosch, David. What is World Literature? Princeton: Princeton UP, 2003.

Dennison, Stephanie, and Song Hwee Lim, eds. Remapping World Cinema:Identity, Culture and Politics in Film. London: Wallflower Press, 2006.

Friederich, Werner. "On the Integrity of Our Planning." In The Teaching of World Literature. Ed. Haskell Block. Chapel Hill: University of North Carolina Press, 196o, 9-22.

Galt, Rosalind, and Karl Schoonover. Global Art Cinema: New Theories and Histories. Oxford: Oxford UP, 2010.

Iordanova, Dina., David Martin-Jones, and Belén Vidal. Cinema at the Periphery. Detroit: Wayne State UP, 2010.

Kurosawa, Akira. "Some Random Notes on Filmmaking." In Something Like an Autobiography. Trans. Audie E. Bock. New York: Vintage, 1983.

Moretti, Franco. Atlas of the European Novel, 1800-19oo. London: Verso, 1998.

Moretti, Franco. "Conjectures on World Literature" and "More Conjectures." New Left Review 1 (2000), 54-68; and 20 (2003), 73-81.

Nagib Lúcia, and Anne Jerslev, eds. Impure Cinema: Intermedial and Intercultural Approaches to Film. London: I.B. Tauris \& Co Ltd., 2014. 
Nagib, Lúcia, Chris Perriam, and Rajinder Dudrah, eds. Theorizing World Cinema. London: I.B. Tauris, 2012.

Ruiz, Raúl. Poetics of Cinema. Vol. I: Miscellanies. Trans. Brian Holmes. Paris: Éditions Dis Voir, 1995 .

Stone, Rob, Paul Cooke, Stephanie Dennison, and Alex Marlow-Mann, eds. The Routledge Companion to World Cinema. Abingdon: Routledge, 2018.

Walkowitz, Rebecca. Born Translated: The Contemporary Novel in an Age of World Literature. New York: Columbia UP, 2015.

Woolf, Virginia. “The Cinema." In The Captain's Deathbed, and Other Essays. London: Hogarth Press, 1950. In The Complete Works. MyBooks Classics, 2018. Kindle edition. WReC (Warwick Research Collective). Combined and Uneven Development: Towards a New Theory of World-Literature. Liverpool: Liverpool UP, 2015. 